\title{
Contact metallurgy optimization for ohmic contacts to InP
}

\author{
Clausen, Thomas; Pedersen, Arne Skyggebjerg; Leistiko, Otto
}

Published in:

21st European Solid State Device Research Conference

Publication date:

1991

Document Version

Publisher's PDF, also known as Version of record

Link back to DTU Orbit

Citation (APA):

Clausen, T., Pedersen, A. S., \& Leistiko, O. (1991). Contact metallurgy optimization for ohmic contacts to InP. In 21st European Solid State Device Research Conference (pp. 157-160). IEEE.

\section{General rights}

Copyright and moral rights for the publications made accessible in the public portal are retained by the authors and/or other copyright owners and it is a condition of accessing publications that users recognise and abide by the legal requirements associated with these rights.

- Users may download and print one copy of any publication from the public portal for the purpose of private study or research.

- You may not further distribute the material or use it for any profit-making activity or commercial gain

- You may freely distribute the URL identifying the publication in the public portal

If you believe that this document breaches copyright please contact us providing details, and we will remove access to the work immediately and investigate your claim. 


\title{
Contact metallurgy optimization for ohmic contacts to InP
}

\author{
Thomas Clausen, Arne Skyggebjerg Pedersen and Otto Leistiko \\ Microelectronics Centre, Techn. Univ. of Denmark, Build. 348, DK-2800 Lyngby
}

\begin{abstract}
AuGeNi and AuZnNi metallizations to n- and p-InP were studied as a function of the annealing temperature in a Rapid Thermal Annealing (RTA) system. For $n-I n P\left(S: 8 \times 10^{18} \mathrm{~cm}^{-3}\right)$ a broad minimum existed from $385^{\circ} \mathrm{C}$ to $500^{\circ} \mathrm{C}$, in which the specific contact resistance, $r_{c}$, was about $10^{-7} \Omega \mathrm{cm}^{2}$. The lowest value of $7 \times 10^{-8} \Omega \mathrm{cm}^{2}$ for n-InP occurred after RTA for 20 sec. at $450^{\circ} \mathrm{C}$. For $\mathrm{p}$-InP $\left(\mathrm{Zn}: 5 \times 10^{18} \mathrm{~cm}^{-3}\right)$ the lowest value of $\mathrm{r}_{\mathrm{c}}, 7 \times 10^{-6} \Omega \mathrm{cm}^{2}$, was obtained for AuZn without any Ni. Metallurgical investigations indicated, that low $r_{c}$ values were associated with interfacial reactions and the formation of stable barrier-lowering metal-phosphides.
\end{abstract}

\section{EXPERIMENTAL}

AuGe/Ni/Au layers on $(100) \mathrm{n}$-InP $\left(\mathrm{S}: 8 \times 10^{18} \mathrm{~cm}^{-3}\right)$ were deposited to a thickness of $1000 / 250 / 500 \AA$ by evaporation and RF sputtering. Evaporated $\mathrm{Au}-12 \mathrm{wt} \% \mathrm{Ge}$ is not homogeneous in depth, a thin Ge layer forms on top. AuZn, Au/AuZn and $\mathrm{AuZn} / \mathrm{Ni} / \mathrm{Au}$ layers on $(100) \mathrm{p}$-InP $\left(\mathrm{Zn}: 5 \times 10^{18} \mathrm{~cm}^{-3}\right)$ were prepared to thicknesses of $1000 \AA, 200 / 1000 \AA$ and 1000/250/500 $\AA$, respectively. Evaporated Au-10wt\% Zn is also not homogeneous, but forms a two-layer structure with a Au layer lying above a $\mathrm{Zn}$ layer. The contact areas, ranging from 100-2000 $\mu \mathrm{m}^{2}$, were defined by standard lithography. The heat treatment was performed in $\mathrm{Ar}$ in a Heatpulse $410 \mathrm{RTA}$ system. The temperature was varied from $300^{\circ} \mathrm{C}$ to $500^{\circ} \mathrm{C}$, and the annealing time was $20 \mathrm{sec}$. The measurement of the specific contact resistance, $r_{c}$, was done using the Cox and Strack technique. Metallurgical investigations included Differential Scanning Calorimetry (DSC) for thermal analysis, X-Ray Diffraction (XRD) for phase identification, Rutherford Backscattering Spectrometry (RBS) for depth resolution of elements and Scanning Electron Microscopy (SEM) for near-surface imaging.

\section{RESULTS}

The contact experiments to $\mathrm{n}-\mathrm{InP}$ showed that a broad minimum exists from $385-500^{\circ} \mathrm{C}$, where the value of $r_{c}$ is about $10^{-7} \Omega \mathrm{cm}^{2}$ (Fig. 1). Note that there is a significant hump in $r_{c}$ at $415^{\circ} \mathrm{C}$. The lowest value, $7 \times 10^{-8} \Omega \mathrm{cm}^{2}$, occurs after an annealing at $450^{\circ} \mathrm{C}$ for $20 \mathrm{sec}$.

The results of the contact experiments to p-InP are shown in Fig. 2. For the AuZn and the $\mathrm{Au} / \mathrm{AuZn}$ metallizations $\mathrm{r}_{\mathrm{o}}$ is minimum after an annealing at $440^{\circ} \mathrm{C} ; 7 \times 10^{-6}$ and $1.4 \times 10^{-5}$ $\Omega \mathrm{cm}^{2}$, respectively. Note, that the onset temperature for low specific contact resistance is low-

0167-9317/91/\$3.50 다 1991 - Elsevier Science Publishers B.V. All rights reserved. 


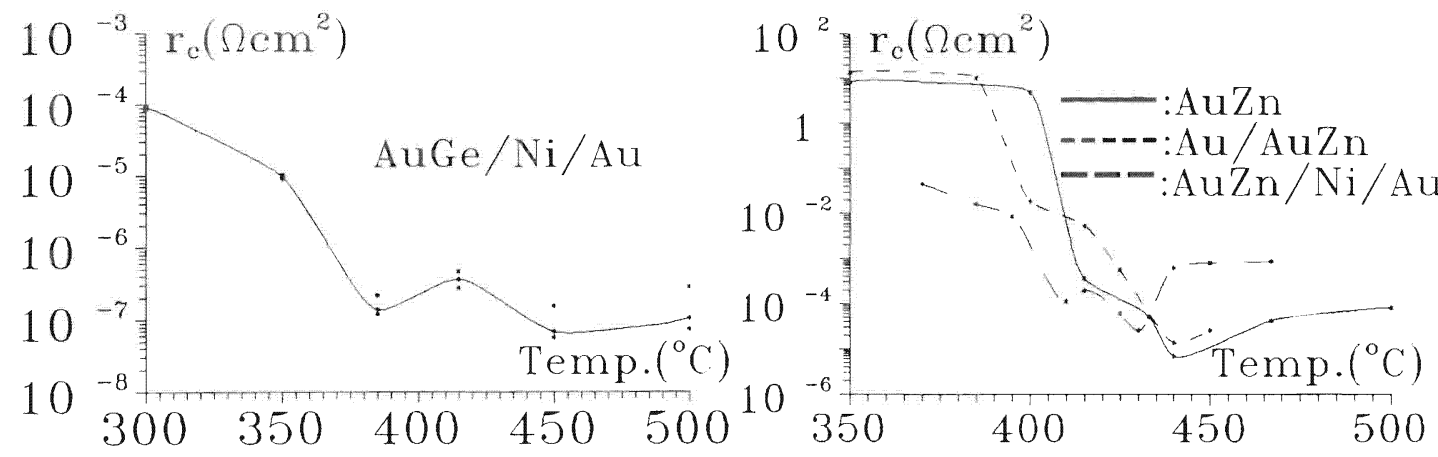

Fig. 1. $r_{c}$ vs. ann.temp. for AuGeNi/n-InP. Fig. 2. $r_{c}$ vs. ann.temp. for AuZn(Ni)/p-InP.

ered by adding the Au layer below the AuZn. However, the lowest obtainable specific contact resistance for the $\mathrm{Au} / \mathrm{AuZn}$ layer is two times larger than for the AuZn layer alone. From Fig. 2 it is also seen, that the addition of $\mathrm{Ni}$ alters the temperature dependence of $r_{c}$ quite drastically. Below $425^{\circ} \mathrm{C} r_{c}$ is lower than for the AuZn layer alone, but again, as for the AuGeNi/n-InP system, there is a hump at $415^{\circ} \mathrm{C}$. The $r_{c}$ minimum $2.7 \times 10^{-5} \Omega \mathrm{cm}^{2}$ occurs at $430^{\circ} \mathrm{C}$. Above $430^{\circ} \mathrm{C} \mathrm{r}_{\mathrm{c}}$ increases abruptly to about $10^{-3} \Omega \mathrm{cm}^{2}$.

The metallurgical investigations showed, that the onset of low values of $r_{c}$ were associated with interfacial reactions between the InP and the AuGeNi or AuZn(Ni), respectively. Examples of this are shown in Fig. 3 and 4, where RBS plots and SEM pictures of AuGeNi and AuZn reactions with InP are shown. The as-deposited layers were smooth and uniform (SEM) and there was no intermixing of the elements (RBS). From DSC of the AuGeNi/InP structure two independent and overlapping exothermic peaks ranging from $200-260^{\circ} \mathrm{C}$ and $240-370^{\circ} \mathrm{C}$ were identified. The termination of the last peak and the onset of minimum $r_{c}$ coincides quite well. For AuZn, the $\mathrm{Zn}$ redistributes below $400^{\circ} \mathrm{C}$ because of the low heating rate of the applied DSC instrument $\left(50^{\circ} \mathrm{C} / \mathrm{min}\right.$. compared to $100^{\circ} \mathrm{C} / \mathrm{sec}$. of the RTA system), and therefore a DSC experiment involving AuZn will be incorrect in determining the onset temperature for RTA reactions. By XRD various Au-In phases were identified: At $440-450^{\circ} \mathrm{C}$ annealing a pink $\mathrm{Au}_{3}$ In phase formed (Fig. 4a) and at $465^{\circ} \mathrm{C}$ a combination of $\mathrm{Au}_{3} \mathrm{In}$ and $\mathrm{Au}_{9} \mathrm{In}_{4}$. At $500^{\circ} \mathrm{C}$ annealing an eutectic melting of AuIn and AuIn $n_{2}$ was detected (Fig. 4b).

\section{DISCUSSION}

It is apparent from the electrical characterization, that $r_{c}$ exhibits an overall minimum for both $\mathrm{AuGeNi}, \mathrm{AuZn}$ and $\mathrm{Au} / \mathrm{AuZn}$ around $440-450^{\circ} \mathrm{C}$, while for the AuZnNi system there is an abrupt increase in $\mathrm{r}_{\mathrm{c}}$ around $440^{\circ} \mathrm{C}$. In this section the role of the metallization elements are discussed individually.

\section{The role of $A u$}

$\mathrm{Au}$ is perhaps the most important element to be discussed, since this is the element that governs the degradation of InP most extensively. Many authors have studied the Au-InP system $^{1-3}$, and a general path in the degradation process may be constructed. Up to 12.7 at $\%$ In is soluble in $\mathrm{Au}$, and this $\mathrm{Au}(\mathrm{In})$ solution is the first step in the process. The next step is the 


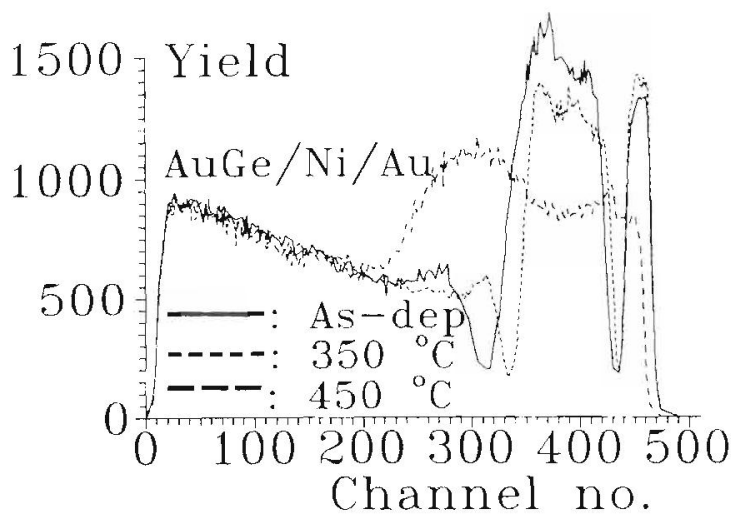

a)

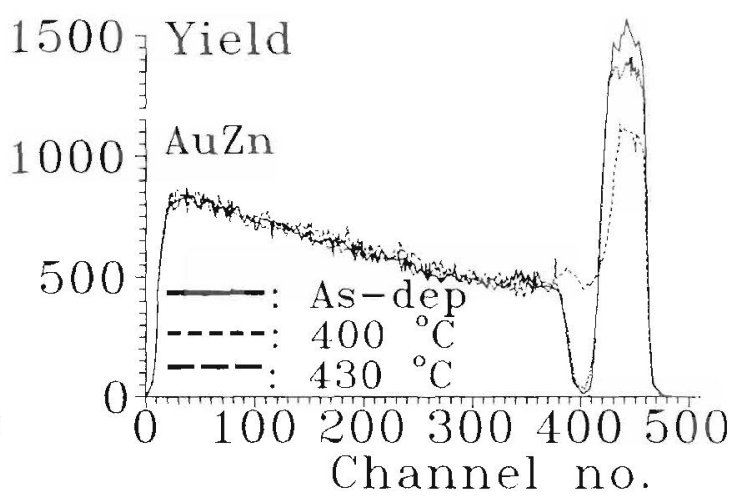

b)

Fig. 3. RBS plots of a) AuGeNi/n-InP and b) AuZn/p-InP reactions.

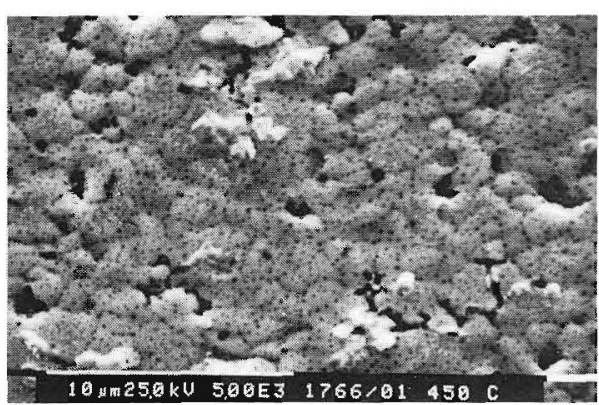

a)

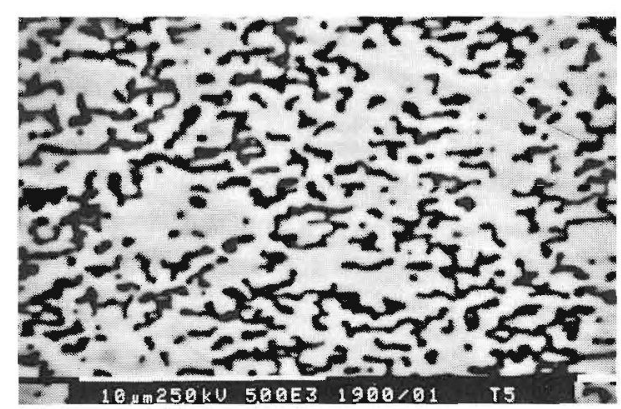

b)

Fig. 4. SEM-picture of a) AuGeNi/n-InP annealed at $450^{\circ} \mathrm{C}$ for $20 \mathrm{sec}$. and of b) $\mathrm{AuZn} / \mathrm{p}-\mathrm{InP}$ annealed at $500^{\circ} \mathrm{C}$ for $20 \mathrm{sec}$.

formation of Au-In phases. Referring to the Au-In binary system' and the Au-In-P ternary system ${ }^{2}$ these are the $\varepsilon$ - and $\gamma$-phases $\left(\mathrm{Au}_{3} \mathrm{In}\right.$ and $\left.\mathrm{Au}_{9} \mathrm{In}_{4}\right)$. Further degradation leads to higherorder $\mathrm{Au}-\mathrm{In}$ phases, but there is some uncertainty about the next phases to be formed. We have detected a AuIn-AuIn ${ }_{2}$ eutectic melting at $500^{\circ} \mathrm{C}$, with no other $\mathrm{Au}$-In phases present between this and the $\gamma$-phase. $\mathrm{Au}$ and $\mathrm{P}$ can only form one phase, the metastable $\mathrm{Au}_{2} \mathrm{P}_{3}$. Formation of both $\mathrm{Au}$-In phases and $\mathrm{Au}_{2} \mathrm{P}_{3}$ only occurs, when the $\varepsilon$-phase is formed. For other $\mathrm{Au}$ In phases, $\mathrm{P}$ either evaporates or is left at the interface between the metals and the $\operatorname{InP}^{3}$.

The lowest $r_{c}$ for $n-$ and $p-\operatorname{InP}\left(430-450^{\circ} \mathrm{C}\right.$ annealing) coincides with a poor morphology and growth of $\mathrm{Au}_{3} \mathrm{In}$. In order to improve this morphology, it is an advantage to involve a melting of the $\mathrm{Au}_{3} \mathrm{In}$ phase $\left(\mathrm{T}_{\text {mol }} \approx 495^{\circ} \mathrm{C}\right)$. A better morphology is also expected to lower $\mathrm{r}_{\mathrm{c}}$ even further. Therefore an experiment was made in which $\mathrm{Au}_{3} \mathrm{In}$ was grown at $370^{\circ} \mathrm{C}$ in a conventionel oven and subsequently melted in the RTA system at $500^{\circ} \mathrm{C}$ for a few seconds. Due to some uncertainty in the annealing time required for growing the $\mathrm{Au}_{3} \mathrm{In} 20,40$ and 90 min. were tested. Annealing for $40 \mathrm{~min}$. gave the lowest $\mathrm{r}_{\mathrm{c}}$ value, $5 \times 10^{-8} \Omega \mathrm{cm}^{2}$, and an almost total coverage of the pink $\mathrm{Au}_{3} \mathrm{In}$ phase. 


\section{The role of $\mathrm{Ge}$ and $\mathrm{Zn}$}

$\mathrm{Ge}$ and $\mathrm{Zn}$ are generally assumed to act as donors and acceptors, respectively, in InP, and they are thought to replace In in the lattice. Various authors have shown the formation of compounds involving $\mathrm{Ge}$ or $\mathrm{Zn}$ adjacent to the InP surface. For $\mathrm{Ge}$, a ternary AuGeP phase is observed ${ }^{5}$, and it is shown that this phase actually lowers the barrier height to $0.15 \mathrm{eV}$. $\mathrm{Zn}$ is shown to react with $\mathrm{P}$, creating $\mathrm{ZnP}$ phases ${ }^{4}$, but there is no information on the electronic properties of these compounds with respect to $\mathrm{p}$-InP.

\section{The role of $\mathrm{Ni}$}

$\mathrm{Ni}$ is important in obtaining low values of $\mathrm{r}_{\mathrm{c}}$ for $\mathrm{n}$-InP (Fig. 1), but for p-InP (Fig. 2) the use of Ni causes an abrupt increase in $r_{c}$ at $440^{\circ} \mathrm{C}$. For a AuZn structure without $\mathrm{Ni}, \mathrm{r}_{\mathrm{c}}$ is minimum at this temperature. Thus, it seems that the electronic properties at the interface changes, and that the changes are associated with phase formations. It has been shown $\mathrm{n}^{5.7}$, that free Ni diffuses through the $\mathrm{Au}(\mathrm{Ge} / \mathrm{Zn})$ layer to the InP surface, where $\mathrm{Ni}(\mathrm{Ge} / \mathrm{Zn}) \mathrm{P}$ phases eventually form. These NiP phases, associated with the exothermic peak from $240-370^{\circ} \mathrm{C}$, are responsible for the changes in the electronic properties ${ }^{8,9}$. For $\mathrm{n}$-InP the barrier height decreases to $0.1 \pm 0.1 \mathrm{eV}$ when NiP phases are formed ${ }^{8,9}$, while the barrier height for $\mathrm{p}$-InP increases. This partly explains the appearance of the curves in Fig. 2. $r_{c}$ is lower for Ni containing contacts below $425^{\circ} \mathrm{C}$ for $\mathrm{p}$-InP, because Ni lowers the reaction temperature. The hump at $415^{\circ} \mathrm{C}$ for both $\mathrm{AuZnNi}$ and AuGeNi contacts to InP are propably associated with two different phase formation regimes due to the addition of $\mathrm{Ni}$. In the first regime, $\mathrm{Ni}$ reactions govern the value of $r_{c}$. In the second regime, reactions between Au and InP preferentially occur, creating first the $\mathrm{Au}(\mathrm{In})$ solution with less $\mathrm{P}$ for $\mathrm{Ni}-\mathrm{P}$ or $\mathrm{Zn}-\mathrm{P}$ reactions and later $\mathrm{Au}_{3} \mathrm{In}$ with more $\mathrm{P}$ adjacent to the InP surface for $\mathrm{Ni}-\mathrm{P}$ or $\mathrm{Zn}-\mathrm{P}$ reactions.

\section{CONCLUSION}

The formation of $\mathrm{a} \mathrm{Au}_{3} \mathrm{In}$ phase during annealing is essential for obtaining low-resistance ohmic contacts to both $\mathrm{n}$ - and $\mathrm{p}$-InP using conventional AuGeNi and AuZn metallization schemes. By growing this phase, a considerable amount of phosphorous will be present at the interface between the metallization and the InP for energetically favorable reactions with $\mathrm{Ge}$, $\mathrm{Ni}, \mathrm{NiGe}$ and $\mathrm{AuGe}$ for $\mathrm{n}-\mathrm{InP}$ and with $\mathrm{Zn}$ or AuZn for $\mathrm{p}$-InP. These metal-phosphides, being thermodynamically stable, lowers the Schottky barrier height, normally believed to be pinned at a certain value, and ensures excellent low-resistance ohmic contacts.

\section{REFERENCES}

1 A. Prince, Phase diagrams of ternary gold alloys, The Institute of Metals, 1990.

2 C.T. Tsai and R.S. Williams, J. Mater. Res., 1(6) (1986) 820.

3 V.G. Weizer and N.S. Fatemi, J. Appl. Phys., 68(5) (1990) 2275.

4 O. Oparaku, Semicond. Sci. Technol., 5 (1990) 65.

5 R.J. Graham and J.W. Steeds, Inst. Phys. Conf. Ser. No. 67 (1983) 507.

6 J.A. del Alamo and T. Mizutani, Solid-State Electronics, 31(11) (1988) 1635.

7 J.B. Boos and W. Kruppa, J. Vac. Sci. Technol., B7(3) (1989) 502.

8 A. Appelbaum, IEEE Trans. Elec. Dev., ED-34(5) (1987) 1026.

9 L.J. Brillson, Appl. Phys. Lett., 38(10) (1981) 284. 